\title{
Assessment of the Use of Maize Storage Structures among Maize Farmers in Ido Local Government Area of Oyo State
}

\author{
Gbadebo Lukman Adebisi, Esther Olufunmilayo Owolade, Bolanle Olufunmilayo Jatto \\ Department of Agricultural Extension and Management, Federal College of Animal Health and Production \\ Technology, Moor Plantation, Ibadan, Nigeria \\ Email: adebisigbadebo2014@gmail.com
}

Received 10 October 2015; accepted 26 October 2015; published 30 October 2015

Copyright (C) 2015 by authors and OALib.

This work is licensed under the Creative Commons Attribution International License (CC BY). http://creativecommons.org/licenses/by/4.0/

(c) (i) Open Access

\begin{abstract}
Part of Nigerian government efforts toward food security and development of agriculture was the provision of an improved maize storage structures to farmers in all local government of the states. Despite this effort, most of the maize farmers in Ido local government area of Oyo state used different indigenous storage structures in stored their maize while some farmers often sell the larger proportion of their produce at harvest. In view of this situation, the research therefore investigated the assessment of use of maize storage structures among maize farmers in Ido local government area of Oyo state. A multistage sampling procedure was used in selecting 120 respondents and the data for this study were obtained through the use of interview schedule which were therefore subjected to analysis. Descriptive statistics and inferential tools were used in describing and making inferences. At p 0.05 level of significance there was correlation between age $(r=$ 0.000), household size $(r=0.000)$, income $(r=0.000)$, constraints $(r=0.000)$, benefits $(r=0.000)$ and the used of maize storage structures. Chi-square analysis also revealed that level of education was significant to the use of maize storage structures $\left(x^{2}=28.03, p=0.000\right)$. The study then concluded that there was low use of maize storage structures due to high cost of an improved storage structure, high cost of used and high cost of storage chemicals. Based on these findings, the study recommended that maize farmers should pool their resources together in order for them to afford an expensive improved storage technologies and credit facilities should be made available to farmers by the government so as to overcome the challenges they are facing in storing maize produce.
\end{abstract}

\section{Keywords}

Assessment, Use of Maize Storage Structure, Maize Farmers

Subject Areas: Agricultural Science, Food Science \& Technology

How to cite this paper: Adebisi, G.L., Owolade, E.O. and Jatto, B.O. (2015) Assessment of the Use of Maize Storage Structures among Maize Farmers in Ido Local Government Area of Oyo State. Open Access Library Journal, 2: e1882.

http://dx.doi.org/10.4236/oalib.1101882 


\section{Introduction}

Maize (Zea mays), known in many English-speaking countries as corns, is a grain domesticated by indigenous peoples of Mesomaria in prehistoric times and it is the most widely grown grain crop in the Americas with 332 million metric tons grown annually in united state alone Raouf [1]. Maize is a versatile crop that grows across a range of agro-ecological zones which serves as an important source of carbohydrate and if eaten in the immature stage, provides useful quantities of vitamin A and C IITA [2]. Maize that also known as corn is the name that has come into common usage primarily because it is used in the United States, the world's largest producer, consumer and exporter of maize Kranja [3].

Maize is an annual plant with high productivity which also enjoys exceptional geographic adaptability, an important property which has helped its cultivation to spread throughout the world Gear [4].

Maize farmers engaged on maize production under various cropping systems and it has now risen to a commercial crop on which many agro-based industries depend on as raw materials Iken and Amusa [5]. According to Ayeni [6] maize has thus grown to be local "cash crop" most especially in the Southwest part of Nigeria where at least $30 \%$ of the crops land has been put to maize production under various cropping systems. Food is man's first and most important necessity of life and the problem of providing enough food of the right kind for everybody is one, which Nigerian farmers are yet to solve. Ojo [7] asserted that food problem has beeen heightened by the relatively low level of productivity of resources used by the farmer in the country. A major problem in agricultural development in the nation has been lack of modern and appropriate storage technologies for grains. Most new improved technological innovation packages are improperly set up and also very expensive for small rural farmers in Nigeria (Agboola [8]). Majunder [9] observed that although many tropical and sub-tropical regions have great potentials for food production because of the enabling climatic conditions, they have not been able to achieve food self-sufficiency because pests, diseases and other agents compete with humans in their struggle to ensure that adequate food is available to meet the population requirements. FAO [10] suggests that food losses even if they are as low as 5\%, should not be ignored, this is because such physical losses are usually accompanied by qualitative losses which affect the whole mass of the grain. According to Asiedu et al. [11] they described the sort of loss as an unfortunate because it lowers the income, standard of living of the farmers and also leads to waste of a large fraction of what is supposed to be a contribution to the nation's food supply. Crop storage plays an integral part in ensuring domestic food supply; however spoilage and total wastage of grains can be minimized through the use of storage technologies (Strahan and Page [12]). Maize as an important staple crop which serves as sources of food for man, an ingredient of poultry and livestock feeds needs to be stored from one harvest to the next in order to maintain its constant supply all year round and to preserve its quality until required for use. Studies have shown that most Nigerian farmers stored maize in various indigenous storage structures for the purpose of self-sustenance and household food security (Alika [13]; Adekunle and Nabinta [14]; Meikle et al. [15]). Despite the desire to store maize in order to cover food requirement and future cash needs, some farmers often sell large proportion of their produce at harvest, when price is low (Whitehead [16]). The importance of maize in the country cannot be overemphasized and little is known about various types of storage systems used by farmers in the major agro-ecological zones of the country. In view of the facts stated above, the study sought to assess the use of maize storage structures among maize farmers in Ido local government area of Oyo.

\subsection{Objectives of the Study}

The general objective of the study is to assess the use of maize storage structures among maize farmers in Ido local Government area of Oyo state

Specific objectives of this study were to:

- describe the socio economic characteristics of the maize farmers.

- describe farm related characteristics of the respondents in the study area.

- identify the maize storage structures that are available in the study area.

- ascertain the frequent use of the maize storage structures.

- determine the benefits derived from the use of maize storage structures.

- identify the constraints to the use of maize storage structures in the study area.

\subsection{Methodology}

The study was carried out in Ido Local Government Area of Oyo state. Ido local government, formally known as 
Akinyele local government was created on May, 1989 and has its headquarter at Ido town. It is located between longitude $2^{\circ} 30 \mathrm{~W} 50^{\circ} 15 \mathrm{E}$ and latitude $6^{\circ} 45 \mathrm{~N}$ and $9^{\circ} 45 \mathrm{~S}$. It occupies a land mass of mass of $865.49 \mathrm{~km}^{2}$ with 57 percent of total used for agricultural purposes (NPC [17]). The study population consists of all maize farmers in Ido Local Government Area of Oyo state. Multistage sampling procedure was used for this study which was as a results of two-stage sampling techniques. The first stage involved the selection of 10 communities from the 14 communities in Ido-local government using simple random sampling technique. The second stage involved the use of proportionate random sampling technique to select 30\% of maize farmers from each of the selected communities from the list of all maize farmers in Ido local government area through extension officers which gives a total sample size of 120 maize farmers that represents the entire population of the registered maize farmers in the local government used for the study.

\subsection{Methods of Data Analysis}

Data obtained from the research conducted were subjected to statistical analysis through the used of statistical methods (Statistical Package For Social Science) that involved in the application of chi-square, Pearson product moment correlation (inferential statistics), frequency and percentage (descriptive statistics).

\subsection{Measurement of Variables}

The dependent variables for this study was the used of maize storage structures among maize farmers. This was measured by listing various types of maize storage structures for the respondents to indicate their level of used after grains had been harvested using a 3 point likert-type scale of always used, occasionally used, not used at all which were scored 2,1.0. Individual scores were computed and mean were determined to categorize the respondents into level of used (high or low). The independent variables include socio-economic characteristics, farm related characteristics, availability of maize storage structures, benefit derived from the used of maize storage structures and constraints to the used of maize storage structures.

\section{Results and Discussion}

\subsection{Respondents' Socio Economic Characteristics}

Table 1 shows data on the socio-economic characteristics of maize farmers. Results indicate that majority of maize farmers (82.5\%) were male and 70.8\% were married. This result finding is in agreement with research conducted by Folayan [18] that reported that majority of the maize farmers were male and married. Also, 30.8\% of them were within the age range of 41 - 50 years which is in line with the results of Anyanwu [19] that reported that the active participants in farming activities were middle aged people. More than half (51.7\%) were Christians, $54.2 \%$ of them had between 4 and 6 persons in their families while 38.3\% of the respondents had no formal education. Findings also showed that $65.8 \%$ of the respondents took farming as their major occupation with $40.8 \%$ of them realized between $\mathrm{N} 1,000$ to $\mathrm{N} 100,001$ as their income.

\subsection{Farm Related Characteristics of the Respondents}

Result of the findings presented in Table 2 showed that $75.0 \%$ of the respondents were into subsistence farming while $25.0 \%$ of them were into commercial farming. This implies that majority of the respondents involved in small scale farming which could affect their decision in storing maize produce. Also, almost half of the respondents (47.5\%) had farm size ranging between 1 to 3 acres of land, 35.8\% of them had between 4 to 6 acres of land, $7.5 \%$ of them had between 7 to 9 acres of land, 3.3\% of them had between 10 to 12 acres of land while the remaining 5.8\% had above 12 acres of land. This implies that most of the respondents had limited access to farm land and therefore have effects on areas of land for the cultivation of maize crops which could affect the use of storage structures since returns on their yield will be very low. It is also showed in the Table 2 that majority of the respondents (65.0\%) were majorly self financed, $14.2 \%$ of them majorly source their finance through banks, $10.8 \%$ of them majorly financed their enterprise through their association members while $10.0 \%$ of the respondents majorly financed their enterprise through their family. This situation could affect their decision about the use of maize storage structures most especially an improved storage structures since most of them are very expensive for them to afford due to their low level of income. Further results also revealed that more than half of 
Table 1. Distribution of respondents based on socio-economic characteristics.

\begin{tabular}{|c|c|c|c|}
\hline Variables & Frequency & Percentage & \\
\hline \multicolumn{4}{|l|}{ Sex } \\
\hline Male & 99 & 82.5 & \\
\hline Female & 21 & 17.5 & \\
\hline \multicolumn{4}{|l|}{ Age } \\
\hline $21-30$ & 17 & 14.2 & \\
\hline $31-40$ & 32 & 26.7 & \\
\hline $41-50$ & 37 & 30.8 & Mean $=43.2$ \\
\hline $51-60$ & 27 & 22.5 & \\
\hline $61-70$ & 7 & 5.8 & \\
\hline \multicolumn{4}{|l|}{ Marital Status } \\
\hline Single & 21 & 17.5 & \\
\hline Married & 85 & 70.8 & \\
\hline Divorced & 12 & 10.0 & \\
\hline Widowed & 2 & 1.7 & \\
\hline \multicolumn{4}{|l|}{ Religion } \\
\hline Islam & 52 & 43.3 & \\
\hline Christianity & 62 & 51.7 & \\
\hline Traditional & 6 & 5.0 & \\
\hline \multicolumn{4}{|l|}{ Household size } \\
\hline $1-3$ & 30 & 25.0 & \\
\hline $4-6$ & 65 & 54.2 & Mean $=4.90$ \\
\hline $7-9$ & 22 & 19.0 & \\
\hline Above 9 & 3 & 2.5 & \\
\hline \multicolumn{4}{|l|}{ Level of Education } \\
\hline No formal education & 46 & 38.3 & \\
\hline Adult education & 16 & 13.3 & \\
\hline Primary education & 35 & 29.2 & \\
\hline Secondary education & 13 & 10.8 & \\
\hline Tertiary education & 10 & 8.3 & \\
\hline \multicolumn{4}{|l|}{ Major Occupation } \\
\hline Teaching & 18 & 15.0 & \\
\hline Farming & 79 & 65.8 & \\
\hline Trading & 20 & 16.7 & \\
\hline Civil service & 2 & 1.7 & \\
\hline Food processing & 1 & 0.8 & \\
\hline \multicolumn{4}{|l|}{ Income (\#) } \\
\hline $1000-100,000$ & 49 & 40.8 & \\
\hline $100,001-200,000$ & 29 & 24.2 & Mean $=\# 170,833.80$ \\
\hline $200,001-300,000$ & 23 & 19.2 & \\
\hline $300,001-400,000$ & 6 & 5.0 & \\
\hline $400,001-500,000$ & 13 & 10.8 & \\
\hline
\end{tabular}


Table 2. Distribution based on farm related characteristics of the respondents.

\begin{tabular}{|c|c|c|c|}
\hline \multicolumn{3}{|c|}{ VARIABLES } & \\
\hline FARMING PRACTICE & FREQUENCY & PERCENTAGE & \\
\hline Commercial & 30 & 25.0 & \\
\hline Subsistence & 90 & 75.0 & \\
\hline \multicolumn{4}{|l|}{ FARM SIZE(ACRES) } \\
\hline $1-3$ & 57 & 47.5 & \\
\hline $4-6$ & 43 & 35.8 & \\
\hline $7-9$ & 9 & 7.5 & Mean $=2.5$ \\
\hline $10-12$ & 4 & 3.3 & \\
\hline Above 12 & 7 & 5.8 & \\
\hline \multicolumn{4}{|l|}{ MAJOR SOURCE OF FINANCE } \\
\hline Self & 78 & 65.0 & \\
\hline Family & 12 & 10.0 & \\
\hline Association members & 13 & 10.8 & \\
\hline Bank & 17 & 14.2 & \\
\hline \multicolumn{4}{|l|}{ MAJOR SOURCE OF LABOUR } \\
\hline Family member & 27 & 22.5 & \\
\hline Paid labour & 20 & 16.7 & \\
\hline Association members & 10 & 8.3 & \\
\hline Self & 63 & 52.5 & \\
\hline \multicolumn{4}{|l|}{ MAJOR SOURCE OF LAND } \\
\hline Personal & 63 & 52.5 & \\
\hline Family land & 29 & 24.2 & \\
\hline Communal ownership & 4 & 3.3 & \\
\hline Rent & 20 & 16.7 & \\
\hline Government & 4 & 3.3 & \\
\hline \multicolumn{4}{|l|}{ STORAGE CAPACITY/TONNE } \\
\hline$<1$ & 75 & 62.5 & \\
\hline $1-2$ & 30 & 25.0 & \\
\hline $3-4$ & 8 & 6.7 & \\
\hline $5-6$ & 7 & 5.8 & \\
\hline
\end{tabular}

the respondents (52.5\%) were self labour in their enterprise which is in contrary with the outcome of the report of Folayan [18] that reported that family labour was the major source of labour in their enterprise, $22.5 \%$ of the respondents made use of their family members as their major source of labour, $16.7 \%$ of the respondents depend on paid labour while $8.3 \%$ of the respondents depends on their association member as their major source of labour It is an evident that most of the respondents were not financially buoyant to employ labour in their enterprise. It is also observed in Table 2 that $52.5 \%$ of the respondents made use of their personal land for maize production, $24.2 \%$ of them made use of family land, $16.7 \%$ of them rent land, $3.3 \%$ made use of government land and community land respectively. This condition discouraged farmers decision to expand their production and therefore not encouraged them to store maize for future use since most of them are producing for immediate consumption and sale after harvesting. Further result of the analysis on Table 2 shows that. $62.5 \%$ of the res- 
pondents stored less than 1 tonne of maize crops per cropping season while $25.0 \%$ of them stored between 1 - 2 tonne per cropping season. This is an indication that majority of the maize farmers were not producing for commercial used which therefore determined their level of use of maize storage structures and even their preferences.

\subsection{Availability of Maize Storage Structures}

The finding of the study revealed that $50 \%$ of the respondents indicated the availability of cribs which corroborates with the findings of Mijinyawa et al. [20] that cribs was of the traditional storage structure available for use in Swaziland. Also, 5.8\% ban, 32.5\% baskets, $12.5 \%$ raised platform, $11.7 \%$ rhombus, $9.2 \%$ metal/plastic drums, $3.3 \%$ earthen/metal pots, $5.0 \%$ plastic/metal buckets, 3.3\% metal tanks, $20.8 \%$ warehouses, $41.7 \%$ rooms, $7.5 \%$ sacks and $5.0 \%$ metal silos were the maize storage structures available in the study area. The implication of this results showed that most of the maize storage structures were not adequately available in the study area with the exception of cribs that is $50 \%$ available (Table 3 ).

\subsection{Frequency Used of Maize Storage Structures}

The results in the Table 4 showed that cribs maize storage structures was $39.2 \%$ used regularly, $14.2 \%$ used

Table 3. Distribution of respondents based on availability of maize storage structures.

\begin{tabular}{ccc}
\hline Maize storage structures & Frequency (Yes) & Percentage \\
\hline Cribs & 60 & 50.0 \\
Bans & 7 & 5.8 \\
Baskets & 39 & 32.5 \\
Raised platform & 15 & 12.5 \\
Rhombus & 14 & 11.7 \\
Metal/plastic drums & 11 & 9.2 \\
Earthen/metal pots & 4 & 3.3 \\
Plastic/metal buckets & 6 & 5.0 \\
Metal tanks & 4 & 3.3 \\
Warehouses & 25 & 20.8 \\
Rooms & 50 & 41.7 \\
Metal silos & 6 & 5.0 \\
Sacks & 9 & 7.5 \\
\hline
\end{tabular}

Table 4. Distribution of respondents based on the frequency used of maize storage structures.

\begin{tabular}{|c|c|c|c|c|c|}
\hline Maize storage structures & Used regularly & Used occasionally & Not used at all & Weighted score & Mean \\
\hline Crib & $47(39.2)$ & $17(14.2)$ & $56(46.7)$ & 111 & 0.93 \\
\hline Bans & $3(2.5)$ & $4(3.3)$ & 113(94.2) & 10 & 0.08 \\
\hline Baskets & $30(25.0)$ & $5(4.2)$ & $85(70.8)$ & 65 & 0.54 \\
\hline Raised platform & $17(14.2)$ & $11(9.2)$ & $92(76.7)$ & 45 & 0.38 \\
\hline Sacks & $9(7.5)$ & $4(3.3)$ & 107(89.2) & 22 & 0.18 \\
\hline Rhombus & $2(2.5)$ & $4(3.3)$ & $114(95.0)$ & 8 & 0.07 \\
\hline Metal/plastic drums & $3(2.5)$ & $6(5.0)$ & $111(92.5)$ & 12 & 0.10 \\
\hline Earthen/ metal pots & $3(2.5)$ & $2(1.7)$ & $115(95.8)$ & 8 & 0.07 \\
\hline Plastic/metal buckets & $3(2.5)$ & $2(1.7)$ & 115(95.8) & 8 & 0.07 \\
\hline Concrete tanks & $1(0.8)$ & $4(3.3)$ & $115(95.8)$ & 6 & 0.05 \\
\hline Warehouse & $17(14.2)$ & $10(8.3)$ & $93(77.5)$ & 44 & 0.37 \\
\hline Rooms & $35(29.2)$ & $13(10.8)$ & $72(60.0)$ & 83 & 0.69 \\
\hline Metal silos & $0(0.00)$ & $6(5.0)$ & 114(95.0) & 6 & 0.05 \\
\hline
\end{tabular}


occasionally, $46.7 \%$ not used at all. Basket was $25.0 \%$ used regularly, $4.2 \%$ used occasionally, $70.8 \%$ not used at all. Rooms was $29.2 \%$ used regularly, $10.8 \%$ used occasionally, $60.0 \%$ not used at all.

\subsection{Respondents Level of Used of Maize Storage Structures}

Level of used of maize storage structures were measured by presenting the respondents the various types of maize storage structures and to indicate how they were used using a 3 point scale of always (2), occasionally (1) and not at all (0). Result of analysis shows a minimum score of 0.00 and maximum score of 26.0 with mean score of 3.64. Respondents with score below the mean of 3.64 were categorized as having high used of maize storage structures while the respondents with mean score and above were categorized as having low used of maize storage structures. Therefore, most of the respondents $(58.3 \%)$ have a low used of maize storage structures and $41.7 \%$ of the respondents have a high used of maize storage structures.

\subsection{Benefits Derived from the Use of Maize Storage Structures}

Table 5 shows that most of the respondents $50.0 \%$, $41.7 \%, 66.7 \%$ and $50.0 \%$ benefitted highly from maize storage structures in terms of how it has buffered their home consumption, increased farm income, preserved the grains for use in the next farming season and maintained the quality of maize grain respectively. Majority of the respondents $85.0 \%, 75.0 \%, 66.7 \%, 62.5 \%$ and $59.2 \%$ indicated that they did not benefit from maize storage structures in terms of how it has improved the knowledge of storing maize grains, reduced price fluctuation of maize grains, reduced post harvest loss, contributed to socio economic aspects of the communities and increased monetary value of maize grain respectively. This may be as a result of the facts that most maize farmers did not involved in the use of maize storage structures which could be attributed to the nature of farming they were practice.

\subsection{Constraints to the Use of Maize Storage Structures}

Table 6 shows that majority of the respondents (66.7\%) indicated that improve storage structures are expensive to afford as their major constraint which could be as a result of their income level that is very low. Also 62.5\% of the respondents indicated that high cost of use an improved storage structures is their major constraint. Further results also revealed that $61.7 \%, 60.0 \%, 58.3 \%, 55.0 \%$ and $54.2 \%$ of the respondents opined that high cost

Table 5. Level of used of maize storage structures.

\begin{tabular}{ccccc}
\hline & Freq & Percent & Minimum & Maximum \\
\hline Low (3.64 and above) & 70 & 58.3 & 0.00 & 26.00 \\
High $(<3.64)$ & 50 & 41.7 & & \\
\hline
\end{tabular}

Table 6. Distribution of respondents according to the benefits derived from use of maize storage structures.

\begin{tabular}{|c|c|c|c|c|c|c|}
\hline Variable & $\begin{array}{c}\text { High } \\
\text { Benefits }\end{array}$ & $\begin{array}{c}\text { Slight } \\
\text { Benefits }\end{array}$ & $\begin{array}{c}\text { No } \\
\text { Benefits }\end{array}$ & $\begin{array}{c}\text { Weighted } \\
\text { score }\end{array}$ & Mean & Rank \\
\hline Buffer home consumption & $60(50.0)$ & $4(3.3)$ & $56(46.7)$ & 124 & 1.03 & $2^{\text {nd }}$ \\
\hline Reduction in postharvest loss & $25(20.8)$ & $15(12.5)$ & $80(66.7)$ & 65 & 0.54 & $6^{\text {th }}$ \\
\hline Increase farm income & $50(41.7)$ & $15(12.5)$ & $55(45.8)$ & 115 & 0.95 & $4^{\text {th }}$ \\
\hline Increase monetary value of maize grain & $40(33.3)$ & $9(7.5)$ & $71(59.2)$ & 89 & 0.74 & 5 th \\
\hline Contribute to socio-economic aspects of the communities & $15(12.5)$ & $30(25.0)$ & $75(62.5)$ & 60 & 0.50 & $7^{\text {th }}$ \\
\hline Reduction in price fluctuation of the maize grains & $10(8.3)$ & 20(16.7) & $90(75.0)$ & 40 & 0.33 & $8^{\text {th }}$ \\
\hline Preserve the grain for use in the next farming season & $80(66.7)$ & $4(3.3)$ & $36(30.0)$ & 164 & 1.36 & $1^{\mathrm{st}}$ \\
\hline Maintain the quality of maize grain & $60(50.0)$ & $4(3.3)$ & $56(46.7)$ & 124 & 1.03 & $2^{\text {nd }}$ \\
\hline Improve the knowledge of storing maize grains & $14(11.7)$ & $4(3.3)$ & $102(85.0)$ & 32 & 0.26 & $9^{\text {th }}$ \\
\hline
\end{tabular}


of storage chemicals, moulding problems on the use of various traditional structures, lack of information on the use of maize storage chemicals, grain germination in various traditional structures and insect infestation on maize grains in the traditional structures were their major constraints respectively.

\subsection{Relationship between Socio-Economic Characteristics of the Respondents and the Use of Maize Storage Structures}

The results of Chi-square analysis as revealed in Table 7 shows that level of education $\left(\chi^{2}=28.032, p=0.000\right)$ of the respondents was significant to the use of maize storage structures. This implies that level of education among the respondents plays a vital role in the use of maize storage structures, it can be inferred that maize farmers with relatively high level of education will take advantage of how maize storage structures can be used.

Similarly in Table 8, the age $(r=-0.245 ; \mathrm{p}=0.009)$, household size $(r=0.335, \mathrm{p}=0.000)$, income $(r=0.456$, $p=0.000$ ) of the respondents were significant to the use of maize storage structures. This implies that the age of the respondents determined the use of maize storage structures because age increases years of experience of the respondents on the use of maize storage structures. Also, income of the respondents determines the use of maize storage structures because the higher the income the more the use of maize storage structures. Respondents with good income would be able to afford the maize storage structures and even the chemicals that involved. On the basis of household size, the increase in the household size results to the increase in the use of maize storage structures because it determines degrees of farming activities of the respondents.

Result in Table 9 shows that there was a correlation between maize farmers constraints and the use of maize storage structures $(r=0.486, \mathrm{p}=0.000)$. This means that the constraints associated with the use of the maize storage structures determines the extents of use of the maize storage structures by the respondents.

Table 7. Distribution of respondents according to their constraints to the use of maize storage structures.

\begin{tabular}{lcccccc}
\hline Constraints & $\begin{array}{c}\text { Major } \\
\text { constraints }\end{array}$ & $\begin{array}{c}\text { Minor } \\
\text { constraints }\end{array}$ & $\begin{array}{c}\text { Not a } \\
\text { constraint }\end{array}$ & $\begin{array}{c}\text { Weighted } \\
\text { score }\end{array}$ & Mean & Rank \\
\hline Improved storage structures are expensive to afford & $80(66.7)$ & $27(22.5)$ & $13(10.8)$ & 187 & 1.56 & $1^{\text {st }}$ \\
High cost of use of improved storage structures & $75(62.5)$ & $25(20.8)$ & $20(16.7)$ & 175 & 1.46 & $2^{\text {nd }}$ \\
Non availability of improved storage structures & $30(25.0)$ & $17(14.2)$ & $73(60.8)$ & 77 & 0.64 & $9^{\text {th }}$ \\
Insect infestation on maize grains in the traditional & $65(54.2)$ & $4(3.3)$ & $51(42.5)$ & 134 & 1.12 & $7^{\text {th }}$ \\
structures & $27(22.5)$ & $37(30.8)$ & $38(31.7)$ & 91 & 0.76 & $8^{\text {th }}$ \\
Rodents attack & $70(58.3)$ & $9(7.5)$ & $41(34.2)$ & 149 & 1.24 & $5^{\text {th }}$ \\
Lack of information on the use of maize storage chemicals & $74(61.7)$ & $16(13.3)$ & $30(25.0)$ & 164 & 1.37 & $3^{\text {rd }}$ \\
High cost of storage chemicals & $72(60.0)$ & $8(6.7)$ & $40(33.3)$ & 152 & 1.27 & $4^{\text {th }}$ \\
Moulding problems on the use of various traditional & $8(6.7)$ & $35(29.2)$ & $77(64.2)$ & 51 & 0.43 & $10^{\text {th }}$ \\
structures & $7(5.8)$ & $35(29.2)$ & $78(65.0)$ & 49 & 0.41 & $11^{\text {th }}$ \\
Leakages of bags and metal tanks & $5(4.2)$ & $26(21.7)$ & $89(74.2)$ & 36 & 0.30 & $12^{\text {th }}$ \\
Collapse of platform, cribs & $66(55.0)$ & $4(3.3)$ & $50(41.7)$ & 136 & 1.13 & $6^{\text {th }}$ \\
\hline Rusting of metal tanks & & & & &
\end{tabular}

Table 8. Chi-square result of socio-economic characteristics of the respondents and the use of maize storage structures.

\begin{tabular}{cccccc}
\hline Variables & $\chi^{2}$-value & Df & Contingency coefficient & D & 0.287 \\
Sex & 2.498 & 2 & 0.142 & 0.247 \\
Marital status & 7.878 & 6 & 0.247 & 0.403 \\
Religion & 16.228 & 4 & 0.344 & NS \\
Level of education & 28.032 & 8 & 0.434 & 0.000 \\
\hline
\end{tabular}


Table 9. Result of Correlation analysis of the relationship between the socio-economic characteristics of the respondents and the use of maize storage structures.

\begin{tabular}{cccc}
\hline Variables & $\mathbf{R}$ & $\mathbf{P}$ & Decision \\
\hline Age & -0.245 & 0.009 & $\mathrm{~S}$ \\
Household size & 0.335 & 0.000 & $\mathrm{~S}$ \\
Income & 0.456 & 0.000 & $\mathrm{~S}$ \\
\hline
\end{tabular}

Table 10. Result of correlation analysis of the respondents constraints and the use of maize storage structures.

\begin{tabular}{cccc}
\hline Variables & r-Value & P-value & Decision \\
\hline Constraints & 0.486 & 0.000 & $\mathrm{~S}$ \\
\hline
\end{tabular}

Table 11. Result of correlation analysis of the respondents' benefits and the use of maize storage structures.

\begin{tabular}{cccc} 
Variables & r-Value & P-value & Decision \\
\hline Benefits & 0.295 & 0.002 & $\mathrm{~S}$ \\
\hline
\end{tabular}

Result in Table 10 indicate that there was a correlation between the respondents benefits and the use of maize storage structures $(r=0.295, \mathrm{p}=0.002)$ (Table 11). This shows that the benefits the maize farmers derived from the use of maize storage structures has effects on the level of use of the maize storage structures, hence it is an essential factor that determine degree of use of maize storage structures.

\section{Conclusion}

This study attempted to determine the assessment of the use of maize storage structures among maize farmers in Ido local government areas of Oyo state. It was discovered that majority of the respondents were male, their major occupation was farming which was majorly self financed and the type of farming they practice is subsistence farming. Many of the maize storage structures were not adequately available for the use of maize farmers including both the traditional structures and improved storage structures which determines their low and non use of the storage structures. Despite the benefits derived from the use of maize storage structures by the respondents, the major constraints to the use of maize expensive improving storage structures that could not be afforded by the maize farmers, high costs of use of maize storage structures and high costs of storage chemicals. Significant relationship exists between level of education, age, household size, income, constraints, benefits and the use of maize storage structures by the respondents.

\section{Recommendations}

Based on the findings of the study, the following recommendations were made:

- Extension agent should be readily available to maize farmers in order to educate them on how to store their maize with the use of storage chemicals;

- Government should provide credit facilities to the farmers in order to have access and make use of the improved storage structures;

- Maize farmers should pools their resources together in order for them to afford an expensive improved storage technologies;

- Storage chemicals should be made available to farmers at a very cheap rate;

- Land use in the study area should be reformed in order for them to have an access to land cultivation.

\section{References}

[1] Raouf, S.S. (2011) Grain Yield and Physiological Growth Indices in Maize (Zea mays L.) Hybrids under Seed Bio 
Priming with Plant Growth Promoting Rhizobacteria (PGRR). Journal of Food, Agriculture and Environment, 9, 393.

[2] International Institute of Tropical Agriculture (IITA) (2001) International Institute of Tropical Agriculture, Annual Report on Maize. IITA Publication.

[3] Kranja, D.M. (2003) The Welfare Effect of Maize Technologies in Marginal and Favoured Regions of Kenya. Unpublished Draft Paper under Review. Michigan State University, East Lansing, M.I.

[4] Gear, J. and Thorbecke, E. (1986) Food Poverty and Consumption Partners in Kenya. Geneva International Labour office, Geneva.

[5] Iken, J.E. and Amusa, N.A. (2004) Maize Research and Production in Nigeria. African Journal of Biotechnology, 302-307. http://dx.doi.org/10.5897/AJB2004.000-2056

[6] Ayeni, A.O. (1991) Maize Production in Nigeria: Problems and Prospects. J. Food Agric., 2, 123-129.

[7] Ojo, S.O. (2004) Efficiency Measurement of Palm Oil Marketing in Ekiti State of Nigeria. African Journal of Business and Econ. Res., 1, 7-12.

[8] Agboola, S.D. (2001) Current Status of the Controlled Atmosphere Storage in Nigeria. Journal of Food Technology in Africa, 6, 30-36. www.Bioline.Org.br/ft

[9] Majumder, S.K. (2005) Approaches to the Assessment of Food Losses. http://www.unu.edu/unupress/food/.htm

[10] FAO (1994) Grain Storage Techniques: Evolution and Trends in Developing Countries. Edited by D.L. Proctor, FAO Consultant, FAO Agricultural Services Bulletin No. 109. Food and Agriculture Organization of the United Nations (FAO), Rome.

[11] Asiedu, E.A., Adusei-Akowuah. P., Van Gastel, A.G.J. and Sallah, P.Y.K. (2002) Effect of Dehumidifiers Drying on the Storage Life of Maize. Tropical Science-London, 42, 167-169. www.direct.bl.uk/research/19

[12] Strahan, R. and Page, J. (2003): Economics of On-Farm Grains Storage and Drying. In: Wright, E.J., Webb, M. and Highley, E., Eds., Proceedings of the Australian Post Harvest Technical Conference, Canberra, December 2003, 1317.

[13] Alika, J.E. (1995) Small Scale Food Crop Preservation. Processing and Product Utilization of Maize. In: Osagie, A.U. Ed., Post Harvest Unit, University of Benin.

[14] Adekunle, O.A. and Nanbita, R.I. (2000) Indigenous Storage Structures for Cereals by Woman Farmers in Kaltungo Area of Gombe State. Journal of Central European Agriculture, 7, 435-438. www.Agr.hr/jcea73-9.pdf

[15] Meikle, W.G., Markham, R.H., Nansen, C., Hoilst, N., Degbey, P., Azoma, K. and Korie, S. (2004) Pest Management in Traditional Maize Stores in West Africa: A Farmer's Perspective. Journal of Economic Entomology, 95, 1079-1088. www.geocities.com

[16] Whitehead, A.J. (1998) Ensuring Food Quality and Safety and FAO Technical Assistance In: Food, Nutrition and Agriculture: Food Standards and International Trade, FAO ISSN 1014-806X (No. 21), 16-17.

[17] National Population Commission (NPC) (1995) National Population Commission, Population Census Report, NPC Publication Report.

[18] Folayan, J.A. (2013) Determinant of Post Harvest Losses of Maize in Akure North Local Government Area of Ondo State. Journal of Sustainable Society, 2, 12-19.

[19] Anyanwu, C.N. (2002) Community Development: The Nigeria Perspective. Gabester Educational Publishers, Ibadan, 2-200.

[20] Mijinyawa, Y., Mwinjilo, M.L. and Dlamini, P. (2006) Assessment of Crop Storage Structures in Swaziland: Agricultural Engineering International. CIGR E-Journal, Vol. 8, No. 22. 